\title{
Microbial population dynamics and diversity during a bloom of the marine coccolithophorid Emiliania huxleyi (Haptophyta)
}

\author{
T. Castberg ${ }^{1}$, A. Larsen $^{1, *}$, R. A. Sandaa ${ }^{1}$, C. P. D. Brussaard ${ }^{2}$, J. K. Egge ${ }^{3}$, M. Heldal ${ }^{1}$, \\ R. Thyrhaug ${ }^{1}$, E. J. van Hannen ${ }^{4}$, G. Bratbak ${ }^{1}$ \\ ${ }^{1}$ Department of Microbiology, University of Bergen, Jahnebakken 5, 5020 Bergen, Norway \\ ${ }^{2}$ Department of Biological Oceanography, Netherlands Institute for Sea Research, PO Box 59, 1790 AB Den Burg, Texel, \\ The Netherlands \\ ${ }^{3}$ Department of Fisheries and Marine Biology, University of Bergen, Bergen High Technology Centre, 5020 Bergen, Norway \\ ${ }^{4}$ Department of Microbial Ecology, Centre for Limnology, Netherlands Institute of Ecology, PO Box 1299, 3600 BG Maarssen, \\ The Netherlands
}

\begin{abstract}
Several previous studies have shown that Emiliania huxleyi blooms and terminations have been succeeded by an increase in large virus-like particles (LVLP), strongly suggesting the bloom collapse was caused by viral lysis. However, due to methodological limitations, knowledge of how such blooms affect the rest of the microbial community is limited. In the current study we induced a bloom of E. huxleyi in seawater enclosures and applied methods enabling us to describe the algae, bacteria and virus communities with greater resolution than has been done previously. The development of the dominating algal, viral and bacterial populations in the nutrient-amended seawater enclosures was followed by flow cytometry (FCM). Light microscopy (LM), PCR-denaturing gradient gel electrophoresis (PCR-DGGE) and pulsed-field gel electrophoresis (PFGE) were used to describe the changes in community composition in greater detail. The algal community was dominated by E. huxleyi until termination of the bloom by viral lysis. After bloom termination the additional algal populations present in the enclosures increased in abundance. A marked increase in viruses other than the one infecting E. huxleyi was also observed. Total bacterial number and community composition were also greatly influenced by the bloom and its collapse.
\end{abstract}

KEY WORDS: Diversity $\cdot$ Emiliania huxleyi $\cdot$ Microbial community · Viral lysis

Resale or republication not permitted without written consent of the publisher

\section{INTRODUCTION}

Viruses are abundant in marine environments and viral termination of phytoplankton blooms has been described in nature (Bratbak et al. 1993, Nagasaki et al. 1995, Suttle \& Chan 1995, Zingone et al. 1999). However, methodological constraints on our ability to study the occurrence and distribution of viruses, bacteria and algae in a large number of samples have

${ }^{*}$ Corresponding author. E-mail: aud.larsen@im.uib.no limited our knowledge of how a bloom and its termination by viruses may affect the remainder of the microbial community.

Mesocosms have frequently been used to describe the impact of various environmental factors on natural phytoplankton communities (e.g. Egge 1993, 1998, Egge \& Heimdal 1994, Jacobsen et al. 1995). Zooplankton and bacterioplankton dynamics have successfully been studied within mesocosms as well (e.g. Nejstgaard 1997, Lebaron et al. 1999, Pinhassi et al. 1999). Previous mesocosm studies have also provided us with knowledge of how to induce blooms of Emilia- 
nia huxleyi in seawater enclosures with reasonable certainty (Egge \& Heimdal 1994). Moreover, descriptions of several incidents of viral terminations of this very species exist from both mesocosms and from natural systems (Bratbak et al. 1993, Egge \& Heimdal 1994, Bratbak et al. 1995, Brussaard et al. 1996).

We have already described how the combination of light microscopy (LM), flow cytometry (FCM), denaturing gradient gel electrophoresis (DGGE) and pulsed-field gel electrophoresis (PFGE) provides an opportunity to establish links between several host and virus populations in mixed natural communities (Larsen et al. 2001, this issue). In the current study we induced an Emiliania huxleyi bloom in seawater enclosures. LM, FCM, DGGE and PFGE were applied in order to follow the bloom and its termination and the effect of these 2 events on the diversity and succession of the rest of the algal, bacterial and viral communities.

\section{MATERIALS AND METHODS}

Experimental design. A mesocosm experiment was carried out at the Marine Biological Field Station, Espeland, $20 \mathrm{~km}$ south of Bergen, western Norway from 25 May to 14 June 1999. The enclosures were mounted on floating frames moored to a raft in the middle of the bay (for details see Egge \& Aksnes 1992). They were $4 \mathrm{~m}$ deep and $2 \mathrm{~m}$ wide (volume $=11 \mathrm{~m}^{3}$ ) and made of $0.15 \mathrm{~mm}$ thick polyethylene $(90 \%$ light penetration, PAR). The enclosures were filled with post-bloom seawater from $2 \mathrm{~m}$ depth, and the water was kept homogenous in the enclosures by means of an airlift.

We enriched the enclosures with nitrate $\left(\mathrm{NaNO}_{3}\right)$ and phosphate $\left(\mathrm{K}_{2} \mathrm{HPO}_{4}\right)$ in order to induce an Emiliania huxleyi bloom (Egge \& Heimdal 1994). The initial nutrient addition raised the concentration of nitrate to $8 \mu \mathrm{M}$ and the concentration of phosphate to $0.5 \mu \mathrm{M}$. The 2 enclosures received smaller amounts of nutrients (4 $\mu \mathrm{M} \mathrm{NaNO}{ }_{3}$ and $0.25 \mu \mathrm{M} \mathrm{K}_{2} \mathrm{HPO}_{4}$ ) on Days 7 and 13 in order to avoid nitrate or phosphate limitation.

Variables measured. Rates and concentrations (primary production, chl $a$, nutrients and abundance of algae, bacteria and viruses) were measured in both enclosures, while the community composition of algae, bacteria and viruses was analysed in Enclosure 1 only. The sampling interval was 1 to $2 \mathrm{~d}$. Seawater temperature and salinity (PSU) was measured with an OTS, Isi Model 85, once a week.

Nitrate, phosphate and silicate concentrations were determined in a Skalar autoanalyser on samples preserved with $1 \%$ (v/v) chloroform (Hagebø \& Rey 1984). The samples were centrifuged at $10000 \times g(\max )$ for
$15 \mathrm{~min}$, in order to remove most particulate matter prior to preservation, and were stored at $10^{\circ} \mathrm{C}$ until analysis.

Primary production was measured by the ${ }^{14} \mathrm{C}$ method (Steeman-Nielsen 1952, Gargas 1975) with modifications as described in Egge \& Jacobsen (1997). Samples for chl a were analysed fluorometrically in a Turner Designs Fluorometer Model 10-AU after filtration on Sartorius membrane filters $(0.45 \mu \mathrm{m})$ and extraction in $90 \%$ acetone (Parsons et al. 1984). Counting and identification of phytoplankton were carried out on samples preserved in Lugol glutaraldehyde (final concentration of $1 \% \mathrm{v} / \mathrm{v}$ ) using the sedimentation method of Utermöhl (1931). Whenever possible, the phytoplankters were identified to species level. Only dominant species are reported, otherwise the species are grouped.

FCM. All FCM analyses were performed with a FACSCalibur flow cytometer (Becton Dickinson, Franklin Lakes, NJ) equipped with an air-cooled laser providing $15 \mathrm{~mW}$ at $488 \mathrm{~nm}$ and with standard filter set-up. The algae were analysed from fresh samples while the enumeration of both viruses and bacteria was performed on glutaraldehyde-fixed samples. The flow cytometer instrumentation and the remaining methodology followed the recommendations of Marie et al. $(1999 a, b)$ and are described in Larsen et al. (2001).

PFGE. Virioplankton agarose plugs were made from the concentrate of 21 water sample, run on a $1 \% \mathrm{w} / \mathrm{v}$ SeaKem GTG agarose (FMC, Rockland, Maine) gel in $1 \times$ TBE gel buffer using a Bio-Rad DR-II CHEF Cell (Bio-Rad, Richmond, CA) electrophoresis unit (Wommack et al. 1999, Larsen et al. 2001). We applied densiometer software and standards with known size and amount of DNA in order to determine the relative abundance of each of the viruses with different genome size.

PCR-DGGE. For bacterial preparations, $10 \mathrm{ml}$ sea water samples were filtered on $0.2 \mu \mathrm{m}$ DynaGard hollow fibre syringe filters (Microgon Inc., Laguna Hills, CA) and stored at $-70^{\circ} \mathrm{C}$ until further processing. The DNA extraction and purification, the PCR amplification using the primer set 338f (Øvreås et al. 1997) with a 40 mer GC clamp in the 5' end and PRU517r (Muyzer et al. 1993), the DGGE and the photographic documentation all followed the description given in Larsen et al. (2001).

DNA preparations for PCR with eukaryotic primers were made as for the bacterial samples with some modifications (Larsen et al. 2001). We performed the PCR-DGGE for the eukaryotes using the protocol exactly as described by van Hannen et al. (1998). Bands from the eukaryote DGGE gels were cut out for DNA sequencing. 


\section{RESULTS}

\section{Abiotic variables, $\operatorname{chl} \mathbf{a}$, and primary production}

The concentrations of nitrate and phosphate in the enclosures were always $>2.2 \mu \mathrm{M}$ and $>0.2 \mu \mathrm{M}$ respectively. The silicate concentration never exceeded $0.7 \mu \mathrm{M}$ and was probably limiting for diatom growth. The temperature increased from an average of 10.1 to $11.0^{\circ} \mathrm{C}$, and the salinity varied between 28.6 and 29.3 PSU during the experimental period (nutrient, temperature and salinity data are not shown in figs below).

The development of biomass and primary production in the enclosures (Enclosures 1 and 2) was similar (Fig. 1). The chl a concentration increased from $1.7 \mu \mathrm{g}$

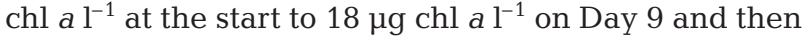
declined. Primary production had 2 maxima, one between Days 7 and 9, with an average carbon production of $19 \mu \mathrm{g} \mathrm{l}^{-1} \mathrm{~d}^{-1}$, and one on Day 15 with $17 \mu \mathrm{g} \mathrm{l}^{-1} \mathrm{~d}^{-1}$.

\section{LM}

The dominating algal species was Emiliania huxleyi, which reached its maximum concentration on Day 11 $\left(2.8 \times 10^{5}\right.$ cells ml $^{-1}$, data not shown $)$. The abundance of small, unidentified flagellates $(<10 \mu \mathrm{m})$ and of prasinophycean species reached maxima of $2.5 \times 10^{4} \mathrm{cells} \mathrm{ml}^{-1}$ and $9.7 \times 10^{3}$ cells ml- ${ }^{-1}$ on Days 13 and 17 respectively

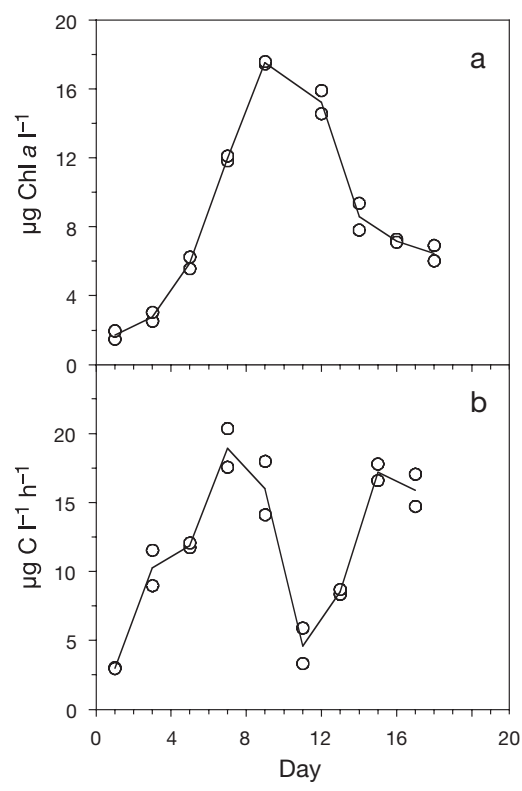

Fig. 1. Enclosures 1 and 2: (a) Biomass, measured as chl $a_{i}$ (b) Primary production. Lines indicate mean values for the 2 enclosures
(Fig. 2). Several other algae were present but the abundance was low and the diatoms were in a poor condition.

\section{FCM}

Two different algae (called A1 and A2) bloomed in the enclosures (Fig. 3a). The development of A1 coincided with the development of the LM-counted Emiliania huxleyi. A1 was characterised by high scatter and red fluorescence values (not shown)-characteristics resembling that of pure cultures of E. huxleyi. The maximum concentration $\left(1.2 \times 10^{5}\right.$ cells ml $\left.{ }^{-1}\right)$ occurred on Day 10 in both enclosures and thereafter declined (Fig. 3a). A2 had lower red fluorescence and scatter signals than A1 and similar characteristics to Synecococcus sp. (not shown). A2 bloomed as A1 declined and reached a maximum concentration of $1.3 \times 10^{5}$ to $1.8 \times$ $10^{5}$ cells ml $^{-1}$ on Day 17 in both enclosures (Fig. 3a). One other algal group (A3), with lower red autofluorescence and scatter values than A1, but higher than A2, was detected in highest numbers at the beginning and at the end of the experiment. A3 is referred to as Micromonas-like due to its FCM characteristics. Four other distinct populations (A4 to A7), generally present in highest numbers towards the end of the experiment, were observed (Fig. 3a). A4 had red fluorescence signals similar to E. huxleyi but lower scatter values and was more abundant than $\mathrm{A} 5, \mathrm{~A} 6$ and A7 combined.

Two major groups of viruses could be distinguished in both enclosures. A virus population (labelled V1)

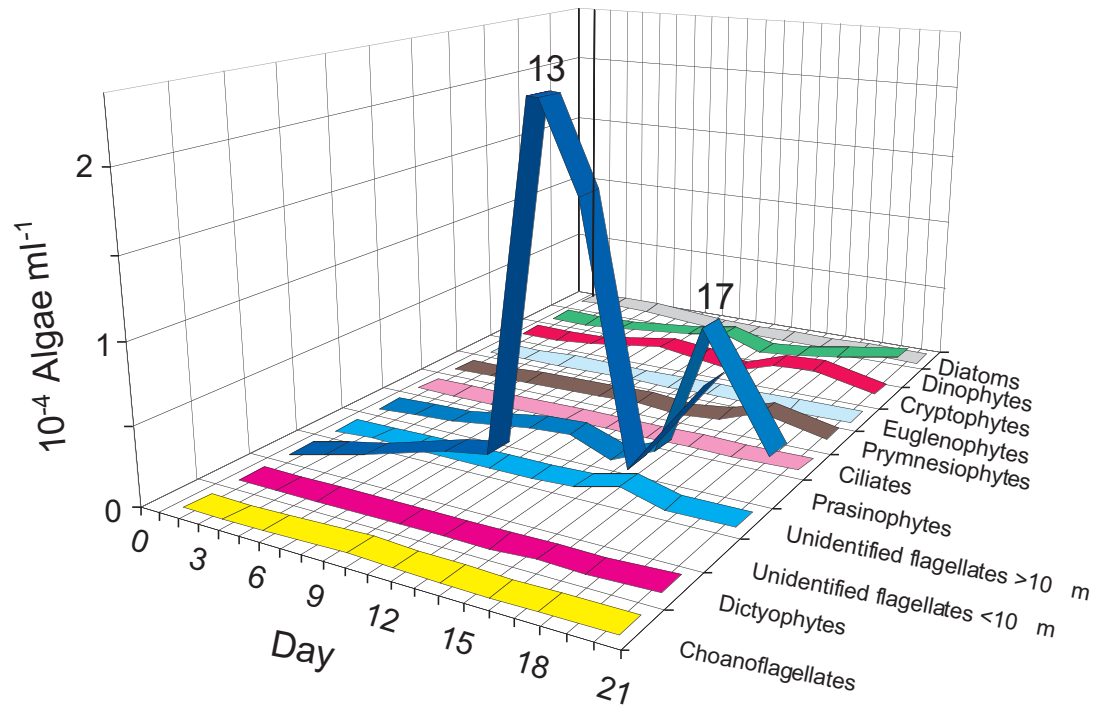

Fig. 2. Abundance of algae and ciliates determined by light microscopy in Enclosure 1. Emiliania huxleyi cell numbers are not included 


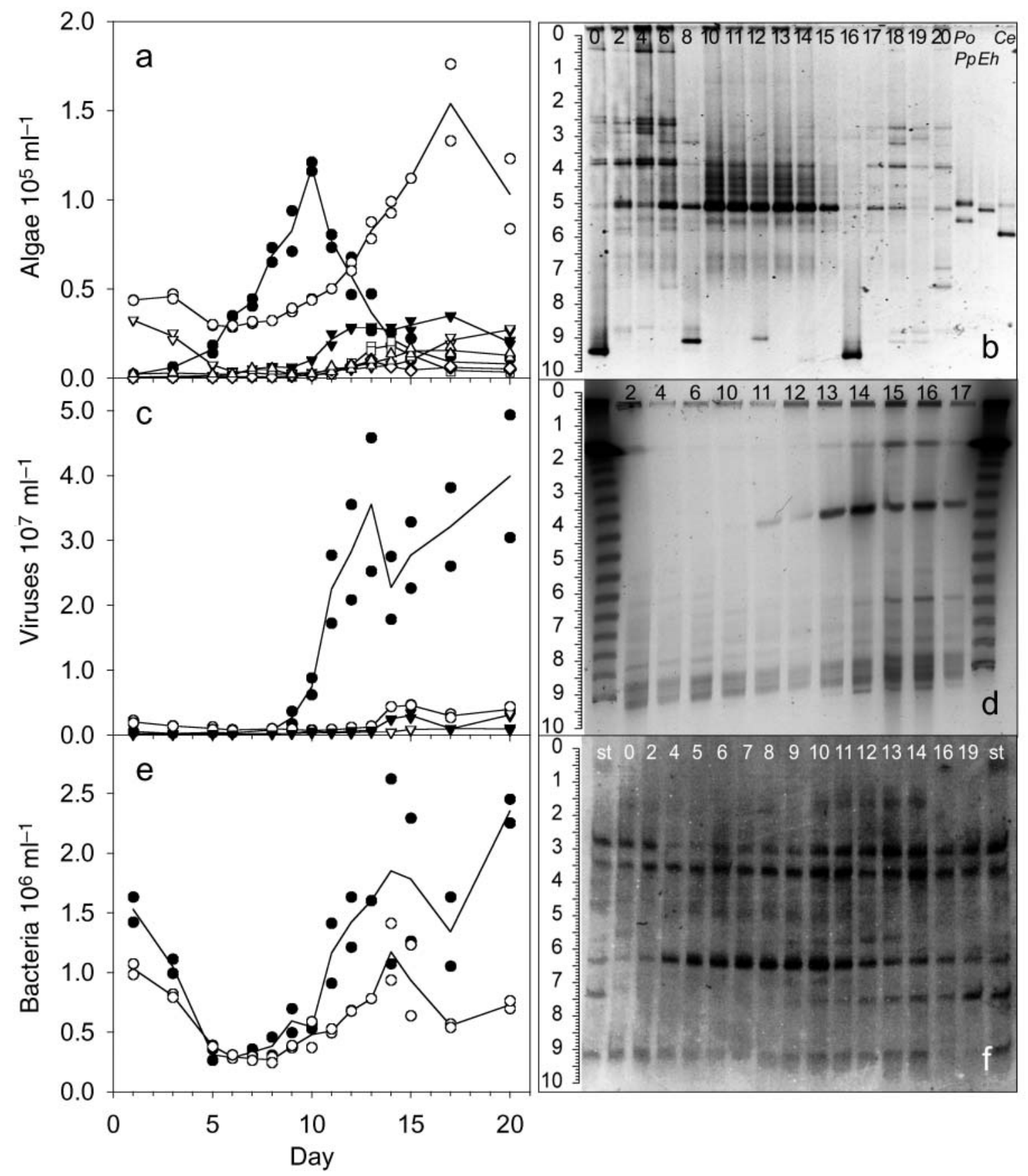

Fig. 3. Development of algae $(a, b)$, viruses $(c, d)$ and bacteria $(e, f)$ determined by flow cytometry $(a, c, e)$, PCR-DGGE (b, f) and PFGE (d) in Enclosures 1 and 2. (a) Abundance of algae. (•) Emiliania huxleyi (A1), (0) Synechococcus sp. (A2), ( $\nabla)$ Micromonas-

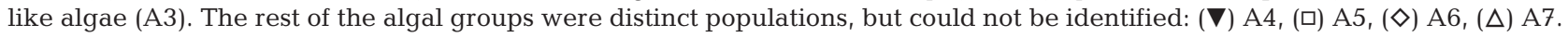
Lines indicate mean values for the 2 enclosures. (b) DGGE profile from analysis of eukaryotic DNA in Enclosure 1. Band positions are indicated by means of the ruler on the left-hand side. Standards used in last 3 lanes are PCR products from pure cultures of the following algae: Pp: Phaeocystis pouchetii, Po: Pyramimonas orientals, Eh: Emiliania huxleyi, Ce: Chrysochromulina ericina. Day numbers are indicated on top of each lane. (c) Abundance of viruses. (•) E. huxleyi virus (V1), (O) Small virus (V2), ( $\nabla)$ Virus with relatively high green fluorescence value indicating high DNA content (V3), ( $\mathbf{\nabla})$ Virus with relatively high side scatter values indicating large size (V4). Lines indicate mean values for the 2 enclosures. (d) PFGE profile from analysis of the viral community. The outermost lane on each side contains phage lambda concatamers from $48.5 \mathrm{kbp}$ to approximately $600 \mathrm{kbp}$. Day numbers are indicated on top of each lane. (e) Abundance of bacteria. (•) Bacteria with relatively high green fluorescence value indicating high DNA content (B1), (O) Bacteria with relatively low green fluorescence value indicating low DNA content (B2). Lines indicate mean values for the 2 enclosures. (f) DGGE profiles from analysis of prokaryotic DNA in Enclosure 1. Band positions are indicated by means of the ruler on the left-hand side. Day numbers are indicated on top of each lane 
with high scatter values (not shown) reached its maximum on Day 13 and remained in high abundance throughout the rest of the experiment (Fig. 3c). The increase in V1 was followed by a sudden decrease in the algal group A1 (Fig. 3a). The virus called V2 had low scatter values (not shown) and increased in abundance on Day 14, i.e. about 1 wk after A3 had started to increase (Fig. 3a,c). Two other viruses, V3 and V4, with maximum abundance at Days 20 and 15 respectively, appeared in both enclosures (Fig. 3c).

The bacteria present in the enclosures could be divided into 2 groups, one (B1) with a higher green fluorescence signal (i.e. DNA content) than the other (B2). The abundance of B1 was equally high or higher than that of B2 (Fig. 3e). In both enclosures, both bacteria groups decreased until Day 6, and subsequently increased and peaked on Days 12 to 14. A new decrease followed by an increase was then observed in both groups. This last increase was more pronounced in B1 than B2.

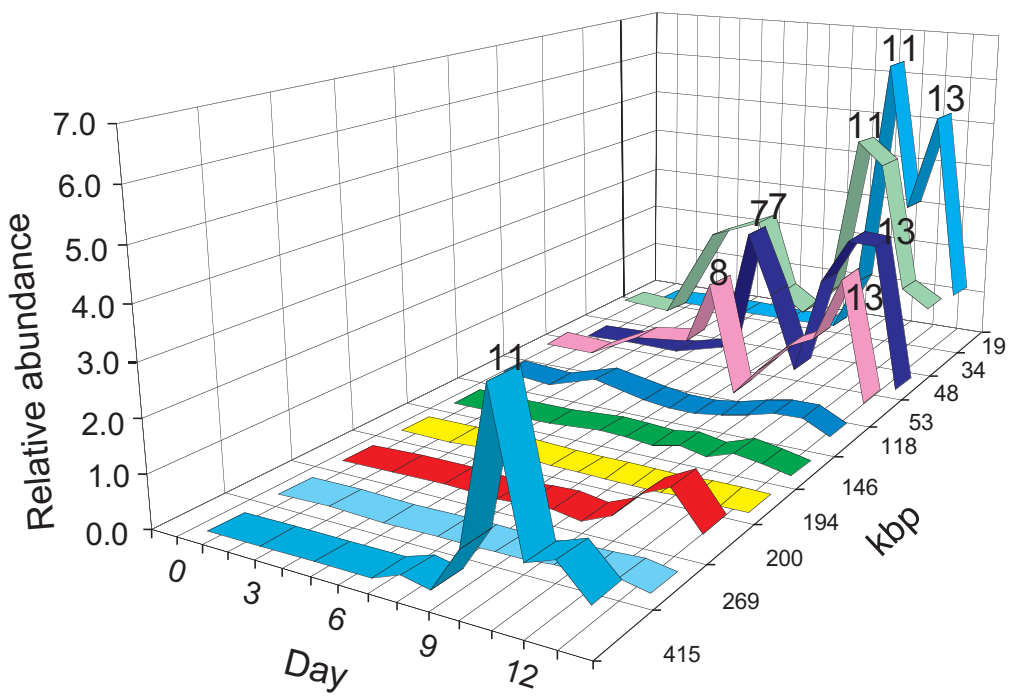

Fig. 4. Relative abundance of distinct virus populations in Enclosure 1 determined by PFGE. The populations are defined by their genome size. The day of maximum abundance is marked on the figure for the most prominent viruses

strong from Day 2 to Day 12. The band position corresponded to the band position of the PCR product from Emiliania huxleyi in culture (Fig. 3b). Moreover, the sequence data from this band on Days 8, 12 and 19 had $100 \%, 98 \%$ and $97 \%$ similarity to E. huxleyi respectively. At the start of the experiment the eukaryote community was composed of 8 to 9 species in equal abundance as judged by band intensity. Two populations clearly present from Days 0 to 5 with bands at position 0.6 and 2.7 disappeared when the E. huxleyiband became dominant (after Day 6). Only 1 other population with a band at position 3.9 was present during the whole experiment. Other bands may, however, have been masked from Days 10 to 15 by the strong E. huxleyi band at position 5.1. The bands in the range from 4.1 to 5.0 are presumably artefacts caused by the strong E. huxleyi band. On Days 0, 6 and 13 the DGGE profile was dominated by 1 strong band at positions 9.1 to 9.5. Eukaryotic bands at these levels are often caused by metazoans (E. J. van Hannen pers. obs.) and the 1 level 9.3 had $93 \%$ sequence similarity with Daphnia pulex. These bands were strong and probably masked less pronounced bands.

The bacterial community present at the start of the experiment (on Days 0 and 2) gave 10 distinguishable bands on the DGGE gel (Fig. 3f). From Day 4 the bacterial community structure changed as the number of bands decreased and 4 bands became dominant (position 2.7, 3.2, 6.2 and 9.2). From Day 9 the bacterial community DGGE profile was again more complex with approximately 10 distinguishable bands. One additional band at level 7.5 also became more dominant from this day on.

With DGGE analysis of the eukaryotic DNA we found from 2 to 11 distinguishable bands on each sampling day, and throughout the entire experimental period we recognised a total of 31 different band positions (Fig. 3b). One band at position 5.1 appeared very 


\section{DISCUSSION}

A bloom of Emiliania huxleyi was induced in 2 seawater enclosures, and we combined LM, FCM, PFGE and PCR-DGGE in order to investigate community composition changes among algae, viruses and bacteria at a species level during the bloom and its termination. Two primary production maxima were observed in the mesocosms, but only the first one corresponded to a maximum peak in biomass. The LM data, the FCM counts and DGGE profile all support that this maximum was caused by E. huxleyi. The LM and the FCM analysis showed an abrupt decrease in E. huxleyi numbers from Day 10 or 11 while the E. huxleyi band dominated until Day 15 on the DGGE profile. The PCR and DGGE may, however, detect non-intact cells, as long as the $18 \mathrm{~S}$ rDNA gene is not broken down. The severe mortality of E. huxleyi was caused by a viral attack. There was no corresponding increase in potential grazers at the time, nutrients were in excess, and the PFGE and FCM data showed that the E. huxleyi maximum was succeeded by a sharp increase in abundance of a specific virus population. A virus infectious to E. huxleyi was at the same time isolated from the enclosures and later propagated in pure culture using E. huxleyi as host (data not shown). The isolated virus had the same FCM characteristics and identical genome size (415 kbp) and particle size (160 nm, measured in transmission electron microscope) as the virus peaking immediately after the E. huxleyi bloom. We are thus for the first time able to present direct evidence that $E$. huxleyi blooms can be terminated by viral activity, as has previously been inferred from circumstantial evidence and the occurrence of large virus-like particles (LVLP) (Bratbak et al. 1993, 1995, Egge \& Heimdal 1994, Brussaard et al. 1996).

Both the Emiliania huxleyi bloom and its viral termination had a considerable impact on the bacterial community. As E. huxleyi flourished during the first half of the experimental period, the total bacterial number decreased substantially, indicating that they lost the competition for available resources. Conversely, the viral lysis of E. huxleyi led to a marked increase in total bacteria numbers. A similar enhancement in bacterial secondary production has been demonstrated in Phaeocystis pouchetii cultures lysed by algal viruses (Bratbak et al. 1998). The bloom, and also the mortality of the E. huxleyi population, had an impact on the bacterial community structure by influencing its diversity and species composition. When comparing the FCM data and the prokaryote DGGE profile, an additional detail of the development of the bacterial community can be found. As the E. huxleyi population rapidly increased, a decrease in the abundance of the high DNA bacteria group relative to the low DNA bacteria group was observed. This change corresponded with the development of a prokaryote community giving a DGGE profile with fewer and more dominating bands, indicating a less diverse bacterial community. The opposite was demonstrated when the E. huxleyi bloom started collapsing. The DGGE profile pattern indicates development towards a more complex bacterial community and the relative abundance of high DNA bacteria increased.

The band at level 3.8 on the eukaryote DGGE gel, which was relatively more prominent at the beginning (Days 0 to 6) and at the end of the experiment (Days 17 to 20) might correspond to the Micromonas-like population (A3) as detected by flow cytometry. This population was present during the whole experimental period. Apart from this the DGGE profile and the LM data demonstrate that the viral-caused termination of the Emiliania huxleyi bloom lead to the establishment of a new eukaryote community. Judged by the LM counts, small unidentified flagellates and prasinophytes were the main components. From the 5 to 6 non-dominating bands on the DGGE profile towards the end of the experiment, we can deduce that these algal groups observed by LM consisted of more than one species. The PFGE results indicated that viruses might have contributed to algal mortality for one or more of these eukaryotic species as 200, 146 and $118 \mathrm{kbp}$-sized viruses all had small maxima around Day 13, when the unidentified flagellates reached their highest concentration. The eukaryote community after the E. huxleyi bloom had fewer dominating populations than the initial eukaryote community, meaning that after the dramatic changes on Day 13 it was probably not yet stabilised when the experiment was ended.

The flow cytometric analyses revealed that another chlorophyll-containing population reached its maximum on Day 17. The maximum abundance of this population corresponded to a peak in primary production but not in biomass. Its properties closely resembled that of Synechococccus sp. with relatively low side scatter and red fluorescence signals but high orange fluorescence signals (not shown). The absence of any strong dominating bands on the eukaryote DGGE profile from Day 13, which would have indicated a clear dominating eukaryote algal population at this time, strongly suggest that this was a cyanobacterial bloom, probably Synechococcus sp. The band at level 7.5 on the prokaryote DGGE profile, becoming increasingly stronger from Day 9 on, might correspond to this population.

Not only did we observe an increase in abundance and diversity of algae and bacteria after the collapse of the Emiliania huxleyi bloom, but also the small-sized viruses (V2 and 19, 34, 48, $58 \mathrm{kbp}$ ) increased after the 
bloom termination. As a decline in the total bacterial abundance and in the Synechococcus population succeeded the blooms of these viruses, it is tempting to suggest that at least some of them are bacteriophages. Although there might well be algal viruses within these size groups, this interpretation is strengthened by the observation that 3 of those $(34,48$ and $58 \mathrm{kbp}$ populations) also bloomed after the decline in the bacteria abundance in the beginning of the experiment. The increase in total bacterial numbers observed at the very end of the experiment (Day 20), might have been a response to an elevated DOC concentration caused by viral mortality of Synechococcus, other prokaryote or even eukaryote populations.

Earlier studies have showed us, by providing counts of the dominating algae (Emiliania huxleyi) and LVLP, that viral lysis might cause termination of E. huxleyi blooms. Several observations of the occurrence of a sharp increase in LVLP simultaneously with the collapse of the blooms permit little doubt that the viruses caused the blooms to collapse (Bratbak et al. 1993, 1995, Egge \& Heimdal 1994). These observations could not, however, describe the impact of the viruses on the remaining microbial community. The current study, using methods allowing for a more detailed description of algal, bacterial and viral diversity, demonstrated that both the bloom and, in particular, its termination by viruses affected the abundance and the diversity of additional algae, bacteria and viruses. The need to utilise a combination of methods, in order to follow and describe the central role viruses play in regulating microbial community structure in marine environments, has thus been clearly demonstrated.

Acknowledgements. This work was supported by grants from The Research Council of Norway (projects 113037/120 and 121425/420). The FACSCalibur flow cytometer was in part funded by a grant from The Knut and Alice Wallenberg Foundation to the Virtue program.

\section{LITERATURE CITED}

Bratbak G, Egge JK, Heldal M (1993) Viral mortality of the marine alga Emiliania huxleyi (Haptophyceae) and termination of algal blooms. Mar Ecol Prog Ser 93:39-48

Bratbak G, Levasseur M, Michaud S, Cantin G, Fernández E, Heimdal BR, Heldal M (1995) Viral activity in relation to Emiliania huxleyi blooms: a mechanism of DMSP release? Mar Ecol Prog Ser 128:133-142

Bratbak G, Jacobsen A, Heldal M (1998) Viral lysis of Phaeocystis pouchetii and bacterial secondary production. Aquat Microb Ecol 16:11-16

Brussaard CPD, Kempers RS, Kop AJ, Riegman R, Heldal M (1996) Virus-like particles in a summer bloom of Emiliania huxleyi in the North Sea. Aquat Microb Ecol 10:105-113

Egge JK (1993) Nutrient control of phytoplankton growth: effects of macronutrient composition (N, P, Si) on species succession. Dr Scient thesis, University of Bergen
Egge JK (1998) Are diatoms poor competitors at low phosphate concentrations? J Mar Syst 16:191-198

Egge JK, Aksnes DL (1992) Silicate as regulating nutrient in phytoplankton competition. Mar Ecol Prog Ser 83: 281-289

Egge JK, Heimdal BR (1994) Blooms of phytoplankton including Emiliania huxleyi (Haptophyta). Effects of nutrient supply in different N:P ratios. Sarsia 79:333-348

Egge JK, Jacobsen A (1997) Influence of silicate on particulate carbon production in phytoplankton. Mar Ecol Prog Ser 147:219-230

Gargas E (1975) A manual for phytoplankton primary production studies in the Baltic. The Baltic Marine Biologists, Publication No. 2. The Danish Agency of Environmental Protection, Hørsholm

Hagebø M, Rey F (1984) Lagring av sjøvann til analyse av næringssalter. Fisken Havet 4:1-12 (in Norwegian with English summary)

Jacobsen A, Egge JK, Heimdal BR (1995) Effects of increased concentration of nitrate and phosphate during a springbloom experiment in mesocosm. J Exp Mar Biol Ecol 187 : $239-251$

Larsen A, Castberg T, Sandaa RA, Brussaard CDP, Egge JK Heldal M, Paulino A, Thyrhaug R, van Hannen E, Bratbak G (2001) Population dynamics and diversity of phytoplankton, bacteria and viruses in a seawater enclosure. Mar Ecol Prog Ser 221:47-57

Lebaron P, Servais P, Troussellier M, Courties C, Vives-Rego J, Muyzer G, Bernard L, Guindulain T, Chäfer H, Stackebrandt E (1999) Changes in bacterial community structure in seawater mesocosms differing in their nutrient status. Aquat Microb Ecol 19:255-267

Marie D, Brussaard CPD, Thyrhaug R, Bratbak G, Vaulot D (1999a) Enumeration of marine viruses in culture and natural samples by flow cytometry. Appl Environ Microbiol 65:45-52

Marie D, Brussaard CPD, Partensky F, Vaulot D (1996b) Enumeration of phytoplankton, bacteria and viruses in marine samples. In: Robinson JP, Darzynkiewicz Z, Dean PN, Orfao A and 4 others (eds) Current protocols in cytometry. John Wiley \& Sons, Chichester, p 11.11.1-11.11.15

Muyzer G, de Waal EC, Uitterlinden AG (1993) Profiling of complex microbial populations by denaturing gradient gel electrophoresis analysis of polymerase chain reactionamplified genes encoding for 16SrDNA. Appl Environ Microbiol 59:695-700

Nagasaki K, Imai I, Itakura S, Ando M, Ishida Y (1995) Viral infection in Heterosigma akashiwo (Raphidophyceae): a possible termination mechanism of the noxious red tide. In: Lassus P, Arzul G, Erard E, Gentien P, Marcaillou C (eds) Harmful marine algal blooms. Intercept Ltd., Andover, p 639-644

Nejstgaard JC (1997) Food web dynamics in flagellatedominated marine environments: trophic interactions between haptophytes, calanoid copepods and microzooplankton. Dr Scient thesis, University of Bergen

Øvreås L, Forney L, Daae FL, Torsvik V (1997) Distribution of bacterioplankton in meromictic Lake Sælenvannet, as determined by denaturing gradient gel electrophoresis of PCR-amplified gene fragments coding for 16S rRNA. Appl Environ Microbiol 63:3367-3373

Parsons TR, Maita Y, Lalli CM (1984) A manual of chemical and biological methods for seawater analysis. Pergamon Press, Oxford

Pinhassi J, Azam F, Hemphälä J, Long RA, Martinez J, Zweifel UL, Hagström Å (1999) Coupling between bacterioplankton species composition, population dynamics, 
and organic matter degradation. Aquat Microb Ecol 17: $13-26$

Steeman-Nielsen E (1952) The use of radioactive $\left({ }^{14} \mathrm{C}\right)$ for measuring organic production in the sea. J Cons Perm Int Expl Mer 18:117-140

Suttle CA, Chan AM (1995) Viruses infecting the marine Prymnesiophyte Chrysochromulina spp.: isolation, preliminary characterization and natural abundance. Mar Ecol Prog Ser 118:275-282

Utermöhl H (1931) Neue Wege in der quantitativen Erfassung des Planktons. (Mit besonderer Berücksichtigung des Ultraplanktons). Verh Int Ver Theor Angew Limnol 5:567-596

Editorial responsibility: Otto Kinne (Editor),

Oldendorf/Luhe, Germany van Hannen EJ, van Agterveld MP, Gons HJ, Landbroek HJ (1998) Revealing genetic diversity of eukaryotic organisms in aquatic environments by denaturing gel electrophoresis. J Phycol 34:206-213

Wommack KE, Ravel J, Hill RT, Chun J, Colwell RR (1999) Population dynamics of Cheapeake Bay virioplankton: total-community analysis by pulsed-field gel electrophoresis. Appl Environ Microbiol 65:231-240

Zingone A, Sarno D, Forlani G (1999) Seasonal dynamics in the abundance of Micromonas pusilla (Prasinophyceae) and its viruses in the Gulf of Naples (Mediterranean Sea). J Plankton Res 21:2143-2159

Submitted: December 29, 2000; Accepted: June 28, 2001 Proofs received from author(s): September 21, 2001 